\title{
TIF film, substrates and nonfumigant soil disinfestation maintain fruit yields
}

\begin{abstract}
by Steven A. Fennimore, Raquel Serohijos, Jayesh B. Samtani, Husein A. Ajwa, Krishna V. Subbarao, Frank N. Martin, Oleg Daugovish, Dan Legard, Greg T. Browne, Joji Muramoto, Carol Shennan and Karen Klonsky
\end{abstract}

\section{A 5-year project to facilitate the adop- tion of strawberry production systems} that do not use methyl bromide initially focused on fumigant alternatives and resulted in increased use of barrier films that reduce fumigant emissions. The focus shifted in year 3 to evaluating and demonstrating nonfumigant alternatives: soilless production, biofumigation, anaerobic soil disinfestation (ASD) and disinfestation with steam. In the 2010-2011 strawberry production season, fruit yields on substrates were comparable to fruit yields using conventional methods. Anaerobic soil disinfestation and steam disinfestation also resulted in fruit yields that were comparable to those produced using conventionally fumigated soils. Additional work is in progress to evaluate their efficacy in larger-scale production systems in different strawberry production districts in California.

alifornia's coastal districts, where $86 \%$ of the nation's strawberries are produced on 38,600 acres, are the most productive strawberry-growing areas in the United States (CSC 2011; NASS 2011). To achieve this level of productivity, California strawberry producers need effective soil disinfestation, productive varieties and cultural practices such as polyethylene mulch and drip irrigation (Strand 2008). Strawberries are very sensitive to soil pathogens, and growers with these highly productive systems have become dependent on preplant fumigation. Traditionally, they used methyl bromide plus chloropicrin $(\mathrm{MB}+\mathrm{Pic})$ as the basis for soil pest control. Fumigation with

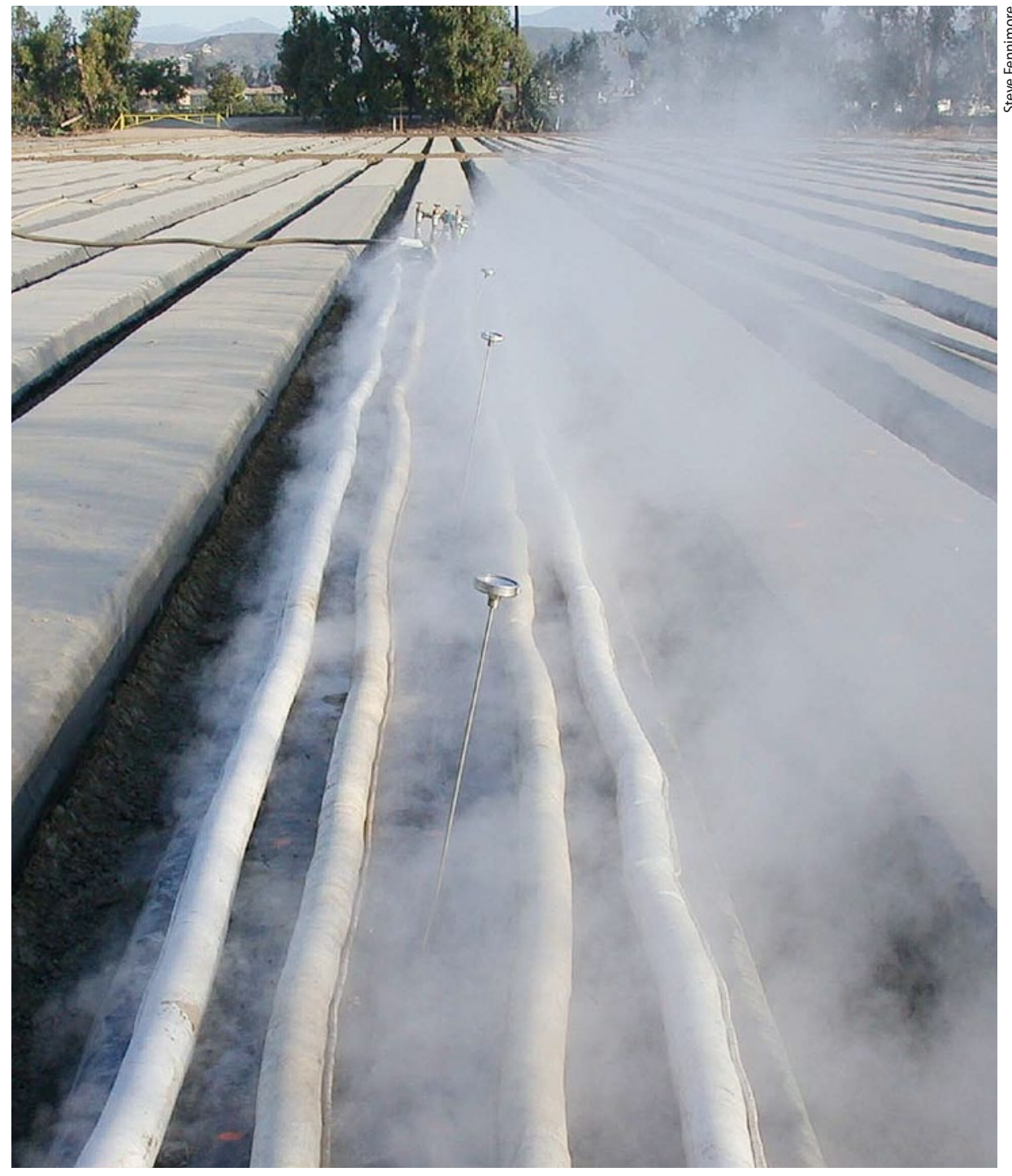

In a multi-year study of strawberry production systems, the use of nonfumigant alternatives such as heat treatment with steam resulted in fruit yields comparable to those produced using conventional fumigants. Above, steam application to strawberry beds prior to planting near Camarillo, CA.

these chemicals controls soilborne pathogens such as Verticillium dahliae, Phytophthora species, Pythium species, Rhizoctonia species, Fusarium oxysporum and Cylindrocarpon species, as well as nematodes, soilborne insects and weed seeds in the soil seedbank (Wilhelm and Paulus 1980). In 1992 methyl bromide was classified as a Class I stratospheric ozone-depleting chemical. Since 2005, under the Montreal Protocol, the use of methyl bromide for fumigation in the United States has been permitted only through critical use exemption (Anbar et al. 1996; USDS 2008).
The methyl bromide phase-out and other regulatory limitations make research on alternative pest control measures essential.

Currently, some California strawberry fields can still be treated with methyl bromide under the critical use exemption, which is subject to annual review by the parties of the Montreal Protocol.

Online: http://californiaagriculture.ucanr.edu/ landingpage.cfm?article=ca.v067n03p139\&fulltext=yes doi: 10.3733/ca.v067n03p139 
However, methyl bromide costs have been increasing, and its use in strawberry production has been decreasing (CADPR 2011). Alternative fumigants being used are 1,3-dichloropropene (1,3-D) and chloropicrin (Pic). In traditional fumigation of California strawberry fields, beginning in the 1960s and continuing until recently, growers applied methyl bromide plus chloropicrin to the total field area. This process was called flat fumigation; the entire field was covered with polyethylene film to hold the fumigant at the concentration needed to kill soil pests (Wilhelm and Paulus 1980). In the last decade, a sizable portion of the strawberry acreage has been treated with fumigants applied to the strawberry bed by drip fumigation (USDS 2008).

The major alternatives to methyl bromide such as 1,3-D and chloropicrin are heavily regulated due to the potential for adverse health effects to workers and nearby populations, which has complicated the transition away from methyl bromide. In California, 1,3-D use per 36-square-mile township is limited to 90,250 pounds, called a township cap, which severely limits its availability in numerous key strawberry production

\section{Fruit yields in the steam treatments and the anaerobic soil disinfestation treatments were comparable to those in the Pic-Clor 60 application.}

areas (Carpenter et al. 2001). A 2008 strawberry critical use nomination indicates that "township caps currently limit the use of $1,3-\mathrm{D}$ on $40 \%$ to $62 \%$ of total strawberry land" (USDS 2008). Chloropicrin is capped at a use rate of 125 pounds near sensitive sites such as day-care centers, and in some counties it cannot be used within one-quarter mile of such sites. Consequently, considerable methyl bromide use continues in California because restrictions on alternative fumigants leave few other options for much of the strawberry acreage.

Currently about $68 \%$ of the California strawberry acreage is fumigated with alternatives to methyl bromide, primarily drip-applied mixtures of 1,3-D plus chloropicrin (InLine, Pic-Clor 60) or chloropicrin emulsified formulation (Pic-EC) (CADPR 2011). Drip fumigation with these products costs less than broadcast shank fumigation with methyl bromide plus chloropicrin. However, there are limits to how much of the remaining $32 \%$ of the strawberry acreage can be converted from methyl bromide to alternative fumigants. Fumigants are difficult to apply evenly by chemigation on hilly fields where beds are not formed along contour lines. Also, all fumigant applications are restricted or not allowed within one-quarter mile of a sensitive site, such as a hospital, jail, school or day-care facility (VCAC 2011).

The public has shown less and less tolerance toward agricultural fumigant use, and regulators have been forced to look for solutions that meet the demands of the public yet allow growers to farm. One strategy to reduce the potential for fumigant exposure from off-site movement of volatile fumigants is the use of barrier films, which trap the fumigant in the field.

\section{Fumigants and barrier films}

A gas-impermeable film can minimize fumigant emissions, increase fumigant retention over time and reduce the amount of fumigant needed for effective pest control (Wang et al. 1999). Compared to standard 1-mil polyethylene films or uncovered soil, virtually impermeable film (VIF) can greatly reduce fumigant emissions and enhance reten-

tion of the fumigant in the upper soil layer (Chellemi and Mirusso 2002). VIF differs from traditional single-layer highdensity polyethylene tarp because VIF has at least one gas-impermeable layer (such as nylon or polyaminides) between polyethylene layers (Wang et al. 1997).

Higher concentrations of 1,3-D and chloropicrin were measured under VIF than under standard film 1 to 4 days after drip fumigation (Desaeger and Csinos 2005). Improved retention of fumigants under VIF provides more opportunity for fumigants to degrade in the soil instead of being released into the atmosphere (Wang and Yates 1998). Researchers have found that VIF can reduce the amount of 1,3-D plus chloropicrin needed for effective soil disinfestation by $50 \%$ (Medina et al. 2006). Santos et al. (2005) found that reducing methyl bromide plus chloropicrin rates by $50 \%$ under multilayer VIF controlled nutsedge similarly to full-rate (350 pounds per acre) methyl bromide plus chloropicrin applied under standard single-layer films.

A relatively new barrier film, totally impermeable film, or TIF, has been shown to retain fumigant better than VIF (Fennimore and Ajwa 2011). TIF is a fivelayer film with two ethylene vinyl alcohol layers embedded in three layers of standard polyethylene film (Fennimore and Ajwa 2011). Fumigant-use regulations in Ventura County allow the application of twice as many pounds of chloropicrin per 48-hour period where TIF is used than under standard 1.25-mil film (VCAC 2011). Fennimore and Ajwa (2011) found that TIF was effective at trapping fumigants, improving weed control and boosting strawberry yields. By trapping the fumigant under TIF, higher fumigant concentrations kill a greater percentage of the weed seeds and soil pathogens, thus improving soil pest control and yields.

\section{Field evaluation of VIF}

We conducted field trials near Salinas at the USDA Agricultural Research Service (USDA-ARS) Spence Farm and near Watsonville at the Monterey Bay Academy research facilities during the 2007-2008 season. Fumigants were applied at Monterey Bay Academy on Oct. 11, 2007, and at Spence Farm on Oct. 24, 2007. The fumigants tested were 1,3-D plus chloropicrin (InLine, 200 pounds per acre; and Pic-Clor 60, 150 pounds per acre), methyl bromide plus chloropicrin (50/50 drip formulation, 200 pounds per acre), and chloropicrin (150 pounds per acre). The efficacy of each treatment was compared to methyl bromide plus chloropicrin (67/33 formulation, 300 pounds per acre) applied by drip fumigation. Each fumigant was applied under two types of film: 1.25-mil VIF (Bruno Rimini, London, UK) and 1.25-mil standard polyethylene tarp.

Approximately 4 weeks after fumigation, the bareroot strawberry variety Albion was transplanted. Beds were 54 inches wide, center to center, and two lengths: 30 feet long at Monterey Bay Academy and 100 feet long at Spence Farm. Due to differences in the land available at the two sites, final harvest plot size was 20 feet long at Monterey Bay Academy and 35 feet long at Spence Farm. Treatments were arranged in a split plot 


\section{Mass transfer coefficient}

The mass transfer coefficient is a measurement of the ability of an agricultural film to block fumigant flow through the film. Every fumigant is different, but using chloropicrin as an example, a standard film would have a mass transfer coefficient in the range of 0.7 to $2.3 \mathrm{~cm} \mathrm{~h}^{-1}$. A VIF or TIF film would have a mass transfer coefficient in a range of 0.0016 to $0.000 \mathrm{~cm} \mathrm{~h}^{-1}$ (Qian et al. 2011).

design, with film as the main plot and fumigant as the subplot, and replicated four times at each site. Conventional tillage practices were followed for strawberry production in each area.

Fruit yield was evaluated once or twice weekly and sorted into marketable fruit and culls. Fruit yield data were analyzed using SAS version 9.3 (SAS Institute, Cary, NC). Data were analyzed for the effects of film on season-long fruit yields, and mean separation was performed using Fisher's protected LSD. The emissions data were analyzed in EXCEL (Microsoft, Redmond, WA) using a student's $t$-test.

The permeability of the two films to 1,3-D, chloropicrin, iodomethane and methyl bromide vapors was monitored using procedures described by Papiernik et al. (2001). Film samples were taken before and after installation, and the average measurement of the flow rate of fumigant through the film (the mass transfer coefficient, MTC, centimeters per hour $\left[\mathrm{cm} \mathrm{h}^{-1}\right]$ ) determined. For each fumigant, the before and after coefficients varied less than $10 \%$, which means that installation did not damage the impermeable layer (Ajwa, unpublished). Across all fumigants, the coefficients varied between 2.7 and 16.9 $\mathrm{cm} \mathrm{h}^{-1}$ for the 1.25-mil standard polyethylene tarp but less than $0.01 \mathrm{~cm} \mathrm{~h}^{-1}$ for VIF, a significant difference for all fumigants (data not shown). The average mass transfer coefficient of VIF was less than $1 \%$ of the average coefficient of the standard tarp. The effect of film on fruit yields was not significant (data not shown).

The work with VIF suggested that it does indeed trap fumigants but does not necessarily improve fruit yields. Recent work with TIF indicated different results. Compared with 1-mil single-layer standard films, TIF resulted in higher fumigant concentrations under the film, higher strawberry fruit yields and better weed control (Fennimore and Ajwa 2011). The work with VIF reported above used a three-layer film with only one impermeable layer; it was a first-generation barrier film. The TIF film, a second-generation film, tested in subsequent studies was a five-layer film with two impermeable layers. The extra impermeable layer in the TIF film may have resulted in greater tolerance to stretching, and thus fewer breaks in the film and better pest control.

\section{Soilless production, no fumigants}

Presently registered alternative fumigants such as 1,3-D, chloropicrin, and 1,3-D plus chloropicrin combinations have been tested and are effective at controlling soil pests in strawberry (Fennimore et al. 2003). However, as described above, regulations limit the use of these products (Carpenter et al. 2001; VCAC 2011). Given the challenges to fumigant use in California, the options for growing strawberries without fumigants must be thoroughly explored. One such option is soilless production.

Strawberry crops can be produced on clean soilless substrates. This production method is commonly used in Europe and does not require methyl bromide. In 2003, 2,815 acres (1,140 hectares) of strawberries were produced using soilless culture in Belgium, the Netherlands, U.K., France and Italy (Lieten, Longuesserre, Pivot 2004). Soilless production of strawberry crops is also being evaluated in Florida (Hochmuth and Hochmuth 2003). Soilless production traditionally used coir, peat or other soilless substrates enclosed in bags under plastic covers, that is, high tunnels (Lieten, Longuesserre, Baruzzi et al. 2004). However, concerns about bag disposal have led to more-sustainable systems, including the raised bed trough system.

Raised bed trough system (RABETS). The bed is made like a typical strawberry bed, with the exception that troughs are cut into it and lined with fabric designed to permit moisture penetration but not allow root penetration. The troughs are filled with clean planting material, steam-treated soil or soilless media; drip tape is installed, and the beds are tarped in the same way as conventional strawberry beds.

The primary justification for using this system is that strawberry crops can

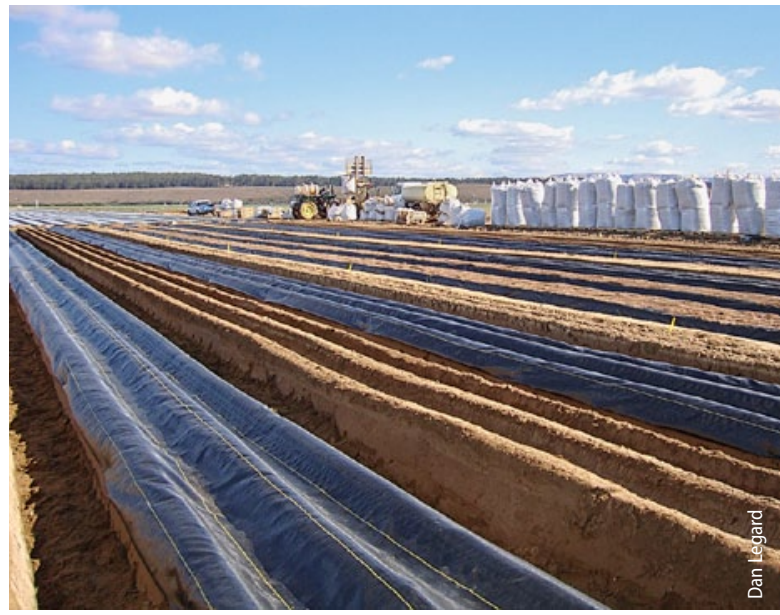

In a raised bed trough system, troughs are cut into each bed and lined with fabric that permits moisture penetration but not root penetration. The troughs are then filled with clean substrate materials. Here at Mar Vista Berry, Santa Maria, yields surpassed those from standard fumigation plots.

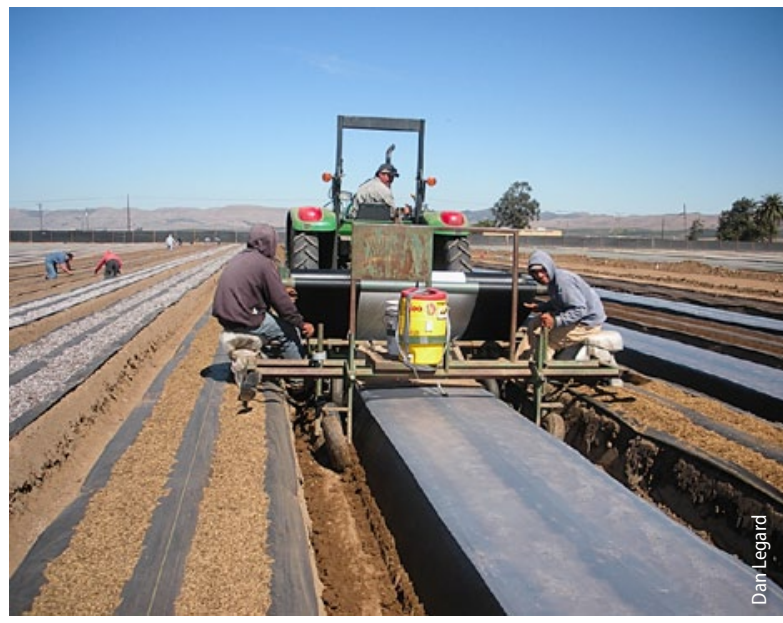

Once the troughs are filled with substrate (left), the beds are covered with film. The beds can be left in place for several crop cycles. No fumigant is used.

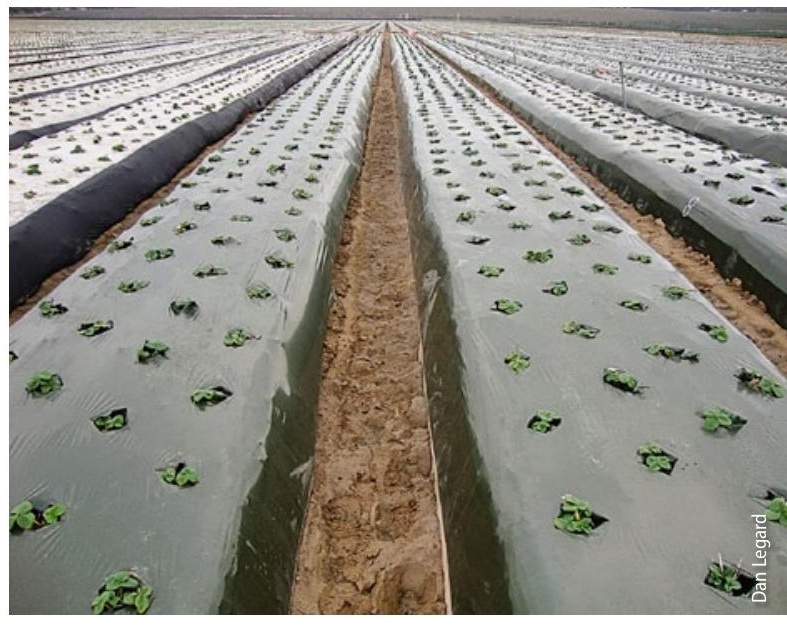

Strawberries planted in substrate at Mar Vista Berry, Santa Maria. One of the main concerns in soilless strawberry production is the maintenance of a favorable $\mathrm{pH}, \mathrm{EC}$ and nutrient supply to the growing plants. 
be produced without fumigation (Lieten, Longuesserre, Pivot 2004); although if the soilless media could be disinfested and recycled, instead of discarded at the end of each cropping cycle, it would, in theory, represent a more sustainable system. Additional advantages include the ease of attracting harvest labor due to the high fruit yield per linear foot of bed row, and the ability to leave the beds in place for several crop cycles. One of the disadvantages is that coir and peat substrates are expensive and of limited quantity. However, composted wood fiber and composted pine bark have shown good results as substrates and are available locally and are generally less expensive (Lieten, Longuesserre, Baruzzi et al. 2004). Logistical issues such as substrate costs and the delivery and installation of large amounts of substrate material have yet to be addressed in U.S. systems.

RABETS field trials. Field trials of a raised bed trough system were carried out at Monterey Bay Academy, near Watsonville, and at Mar Vista Berry, near Santa Maria, from fall 2010 to summer 2011. The studies were set up in randomized complete block designs consisting of five treatments replicated four times. The treatments were $100 \%$ coir (coconut hull fiber), a 70:30 peat and perlite mixture, an amended soil mix of $50 \%$ steamed soil plus $25 \%$ rice hulls and $25 \%$ coir, a standard fumigation treatment (MB + Pic), and an untreated, nonfumigated control. Harvesting was done from April 28 to Sept. 15, 2011 (Monterey Bay Academy), and April 13 to Oct. 4, 2011 (Mar Vista Berry, Santa Maria). The fruit was sorted into marketable berries and cull (nonmarketable). Periodic collection of substrate samples was done to monitor $\mathrm{pH}$, electrical conductivity (EC), nitrate nitrogen $\left(\mathrm{NO}_{3}-\mathrm{N}\right)$, ammonium nitrogen $\left(\mathrm{NH}_{4}-\mathrm{N}\right)$ and available phosphorus (P). All data were subjected to analysis of variance (JMP version 8; SAS Institute, Cary, NC), and Fisher's protected LSD at 0.05 was used to compare means.

Table 1 shows the plant diameters and yields of strawberry crops grown in the plots at Monterey Bay Academy and Mar Vista Berry. There were highly significant differences in plant diameter and yield (marketable, cull and total) of strawberries grown at Monterey Bay Academy. The widest plant diameter (10.46 inches) was from plants grown in the peat and perlite system. The three substrate treatments (coir, peat and perlite, and steamed soil with amendments) did not significantly differ in marketable yield. The untreated, nonfumigated control treatment had the smallest plant diameter and lowest marketable yield. The marketable yield of the coir, peat and perlite, and steamed soil with amendments treatments was $27 \%$, $29 \%$ and $13 \%$ higher, respectively, than the yield from the standard fumigated treatment.

At Mar Vista Berry (Santa Maria), the widest plant diameters were in the steamed soil with amendments plots (10.25 inches) and the peat and perlite substrate plots (9.86 inches). However, the substrate treatments did not affect the marketable fruit yield. Significant differences were noted only on the cull yield. The highest cull yield was observed in the steamed soil with amendments; this was the case at both Mar Vista Berry and Monterey Bay Academy, and it could be attributed to the very low $\mathrm{pH}$ and high EC (electrical conductivity) of this substrate.

One of the main concerns in soilless strawberry production is the maintenance of a favorable $\mathrm{pH}, \mathrm{EC}$ and nutrient supply to the growing plants. For most of the sampling periods at the experimental sites, different substrate and soil treatments had significantly different levels of $\mathrm{pH}, \mathrm{EC}$, nitrate nitrogen, ammonium nitrogen and available phosphorus.

At both sites, the $\mathrm{pH}$ of the coir and the peat and perlite treatments was lower in the early sampling periods but increased with time, reaching the targeted value of 5.7 after 3 to 4 months (data not shown); this slow rise in $\mathrm{pH}$ to the target value was attributed to the high nutrient adsorptive capacity of the soilless substrates. The $\mathrm{pH}$ of the amended soil treatments at both sites was generally low at all sampling periods, and the target value was not reached during the production cycle.

With the exception of the initial sampling period, the EC of the substrate treatments at Monterey Bay Academy was generally low $(<2.0 \mathrm{mS} / \mathrm{cm})$. In contrast, the EC in the Mar Vista Berry beds was consistently high, which could be due to the higher amount of salts in the irrigation water. The EC of the steamed soil with amendments treatment at Mar Vista Berry was also consistently high throughout the growing season.

The soilless substrates are low in nutrients; thus, fertilization is one of the key issues in these systems. Surprisingly, the initial nitrate nitrogen of the coir and the peat and perlite mixture was higher at both sites, and the target value of $100 \mathrm{ppm}$ was maintained in the beds through the season except for the latter stages of plant growth (table 2). The standard fumigated
TABLE 1. Strawberry plant diameter and yield at Monterey Bay Academy and Mar Vista Berry, as affected by different substrates, 2010-2011

\begin{tabular}{|c|c|c|c|c|c|}
\hline \multirow[b]{2}{*}{ Treatment } & \multirow{2}{*}{$\begin{array}{c}\text { Plant } \\
\text { diameter }\end{array}$} & \multicolumn{3}{|c|}{ Yield } & \multirow{2}{*}{$\begin{array}{l}\text { Percentage of } \\
\text { relative yield }\end{array}$} \\
\hline & & Marketable & Cull & Total & \\
\hline & inches & $\ldots \ldots \ldots \ldots$ & . Ib/plant & $\ldots \ldots \ldots \ldots$ & \\
\hline \multicolumn{6}{|l|}{ Monterey Bay Academy } \\
\hline Coir & $9.63 b^{*}$ & $3.26 a$ & $1.52 \mathrm{bc}$ & $4.77 a$ & $127 a$ \\
\hline Peat and perlite & $10.46 a$ & $3.26 a$ & $1.65 a b$ & $4.91 a$ & $129 a$ \\
\hline Steamed soil with amendments & $9.18 \mathrm{bc}$ & 2.89ab & $1.72 a$ & $4.61 a$ & $113 a b$ \\
\hline Standard fumigation & $8.56 \mathrm{c}$ & $2.57 \mathrm{~b}$ & $1.38 c$ & $3.95 b$ & $100 \mathrm{~b}$ \\
\hline Untreated control & $7.40 \mathrm{~d}$ & $0.90 c$ & $0.72 d$ & $1.62 c$ & $35.3 c$ \\
\hline Probability $>F$ & $<0.0001$ & $<0.0001$ & $<0.0001$ & $<0.0001$ & $<0.0001$ \\
\hline \multicolumn{6}{|l|}{ Mar Vista Berry } \\
\hline Coir & $9.61 b c$ & 1.93 & $1.21 \mathrm{bc}$ & 3.14 & 100 \\
\hline Peat and perlite & $9.86 a b$ & 1.91 & $1.26 \mathrm{ab}$ & 3.18 & 99 \\
\hline Steamed soil with amendments & $10.25 a$ & 1.83 & $1.33 a$ & 3.16 & 95 \\
\hline Standard fumigation & $9.24 c$ & 1.94 & $1.14 \mathrm{~cd}$ & 3.08 & 100 \\
\hline Untreated control & $8.66 d$ & 1.91 & $1.10 d$ & 3.01 & 99 \\
\hline Probability $>F$ & $<0.0001$ & 0.6710 & 0.0006 & 0.2467 & 0.7505 \\
\hline
\end{tabular}

* Mean values within a column followed by the same letter(s) or without letters were not significantly different according to Fisher's LSD test $(P>0.05)$. 
beds had generally low nitrate nitrogen. At all sampling periods, the ammonium nitrate was lower than the RABETS target value of $14 \mathrm{ppm}$ (data not shown).

The RABETS target of 30 ppm available phosphorus was maintained in all of the media treatments at both sites (data not shown).

\section{Anaerobic soil disinfestation}

Anaerobic soil disinfestation (ASD), a nonchemical alternative to methyl bromide, was developed in Japan (Momma 2008) and the Netherlands (Blok et al. 2000) to control soilborne pathogens and nematodes in strawberries and vegetables. Anaerobic soil disinfestation integrates the principles of solarization and flooding in situations where neither method alone is effective or feasible. Anaerobic soil conditions are created by incorporating readily available carbon sources into topsoil, covering the soil with plastic tarp and irrigating to field capacity. The tarp is left in place to maintain soil moisture above field capacity and to sustain anaerobic conditions. Anaerobic decomposers respire using the added carbon, which results in a buildup of anaerobic byproducts that are toxic to pathogens (Katase et al. 2009). These byproducts degrade rapidly once the tarp is removed or holes are punched through the tarp for planting.

Studies were conducted during 2008 to 2011 in an attempt to optimize anaerobic soil disinfestation for California strawberry and Florida vegetable production systems. Overall, it was very effective in suppressing Verticillium dahliae in soils, and it resulted in $85 \%$ to $100 \%$ of the marketable fruit yield observed with fumigated controls in coastal California strawberries when 9 tons per acre of rice bran was preplant incorporated and 3 to 4 acre-inches of irrigation was applied in sandy loam to clay loam soils (Shennan et al. 2011).

In the semitropical climate of Florida, when composted broiler litter (to improve the water-holding capacity of Florida's sandy soil) and heavy blackstrap molasses were incorporated as substrate, anaerobic soil disinfestation treatments provided good control of nutsedge and excellent control of grasses, broadleaf weeds, Phytophthora capsici and Fusarium oxysporum f. sp. lycopersici (Rosskopf et al. 2010). In the cooler conditions of the Central Coast, however, anaerobic soil

TABLE 2. Nitrate nitrogen values* in Monterey Bay Academy and Mar Vista Berry substrate trials, 2010-2011

\begin{tabular}{|c|c|c|c|c|c|c|c|c|}
\hline \multirow[b]{2}{*}{ Treatment } & \multicolumn{4}{|c|}{ Monterey Bay Academy } & \multicolumn{4}{|c|}{ Mar Vista Berry } \\
\hline & $\begin{array}{c}\text { Nov } 18 \\
2010\end{array}$ & $\begin{array}{c}\text { Mar } 11 \\
2011\end{array}$ & $\begin{array}{c}\text { June } 16 \\
2011\end{array}$ & $\begin{array}{l}\text { Sep } 9 \\
2011\end{array}$ & $\begin{array}{c}\text { Nov } 12 \\
2010\end{array}$ & $\begin{array}{c}\text { Mar } 8 \\
2011\end{array}$ & $\begin{array}{c}\text { Jun } 14 \\
2011\end{array}$ & $\begin{array}{l}\text { Sep } 8 \\
2011\end{array}$ \\
\hline Coir & 145.9a† & $135.0 \mathrm{a}$ & $39.5 b$ & $25.9 b$ & $160.4 b$ & $112.0 \mathrm{~b}$ & $141.8 \mathrm{a}$ & 29.3 \\
\hline Peat and perlite & $92.2 b$ & $152.5 a$ & $68.7 a$ & $37.8 a$ & $210.9 a$ & $177.4 a$ & $155.1 \mathrm{a}$ & 33.4 \\
\hline $\begin{array}{l}\text { Steamed soil with } \\
\text { amendments }\end{array}$ & $32.4 \mathrm{c}$ & $70.5 b$ & $12.6 c$ & $32.1 \mathrm{ab}$ & $94.3 c$ & $49.6 c$ & $145.0 \mathrm{a}$ & 29.8 \\
\hline Standard fumigation & $15.0 \mathrm{~d}$ & $4.7 c$ & $1.2 \mathrm{c}$ & $27.7 \mathrm{~b}$ & $38.5 d$ & $7.1 d$ & $21.2 b$ & 38.5 \\
\hline Untreated control & $15.0 \mathrm{~d}$ & $5.0 c$ & $0.9 c$ & $23.0 \mathrm{~b}$ & $39.6 d$ & $4.4 d$ & $7.3 b$ & 37.4 \\
\hline Probability $>F$ & $<0.0001$ & $<0.0001$ & $<0.0001$ & 0.0328 & $<0.0001$ & $<0.0001$ & $<0.0001$ & 0.4975 \\
\hline
\end{tabular}

disinfestation may not provide effective control of many weed species (unpublished data).

To ensure consistency of pest suppression across varying locations, the effects of soil temperatures and treatment length and the mechanisms of pest suppression by anaerobic soil disinfestation are being further elucidated. Its integration with other nonfumigant approaches may also have promise. For example, a combination of anaerobic soil disinfestation and mustard seed meal application is currently being tested (Shennan and Muramoto, unpublished).

\section{Soil disinfestation with steam}

Heat treatment with steam can be used for soil sterilization or pasteurization (Samtani et al. 2012). Studies have shown that most plant pathogens, insects and weeds will die when moist soils are heated to temperatures higher than $150^{\circ} \mathrm{F}\left(65^{\circ} \mathrm{C}\right)$ for 30 minutes (Baker and Roistacher 1957). The duration and amount of steam needed to raise the soil temperature to $150^{\circ} \mathrm{F}$ depend on various soil factors, including texture, type and moisture content. Minuto et al. (2003) found that soil could be heated most rapidly at a moisture content between $8.5 \%$ and $12 \%$ in a sandy loam and between $6 \%$ and $7 \%$ in a sandy soil. Steam applied to field soil that raised the temperature to $158^{\circ} \mathrm{F}$ for 20 minutes resulted in weed control comparable to methyl bromide (Samtani et al. 2012).

In addition to pest control, an advantage of steaming is that it lacks the negative environmental and worker health issues associated with chemical fumigants. Some have reported that steaming has little or no lasting negative impact on soil quality or soil microbial communities (Jäderlund et al. 1998; Zackrisson et al. 1997) as opposed to the known potential impact of methyl bromide fumigation on both soil quality and microbes (Ibekwe et al. 2001; Yamamoto et al. 2008). Other studies have reported a more significant change in soil microbial activity due to steam sterilization (Tanaka et al. 2003; Yamamoto et al. 2008). Differences among steam studies may be related to duration of steam application and soil temperatures attained during steam treatments as well as the soil organic matter content.

Steam has also been shown to increase crop growth and yields (Moyls et al. 1994). Previous work found that strawberry fruit yields from steam-treated soils were similar to those from soils fumigated with methyl bromide plus chloropicrin (Samtani et al. 2012).

\section{Biofumigants}

Natural products such as mustard seed are being evaluated as biofumigants. Recent studies found that mustard seed meal amendment can suppress root infection by Rhizoctonia solani (Mazzola 2006). We have been testing mustard seed meal (BioFence, Green Envy) in strawberry beds at rates of 500 to 4,000 pounds per acre incorporated into the soil. Mustard meal alone does not consistently produce high fruit yields or control weeds (Samtani et al. 2011). One possible method to enhance solarization is to use combinations of mustard meal, chloropicrin, and metam sodium treatments (Chellemi and Mirusso 2006). By heating the soil with solarization or steam, the pest control activity of metam sodium, chloropicrin or mustard meal may be higher than at ambient soil temperatures. 


\section{ASD, mustard seed meal and steam}

A field study was conducted at Monterey Bay Academy from October 2010 to September 2011 to evaluate anaerobic soil disinfestation and steam with and without mustard seed meal application prior to planting strawberry beds. Treatments included a control; Pic-Clor 60 at 300 pounds per acre as a standard; mustard seed meal at 3,000 pounds per acre; anaerobic soil disinfestation with rice bran at 9 tons per acre; anaerobic soil disinfestation with rice bran at 7.5 tons per acre and mustard seed meal at 3,000 pounds per acre; steam; and steam plus mustard seed meal at 3,000 pounds per acre.

Trial design. The trial was arranged in a randomized complete block design with four replicates. Anaerobic soil

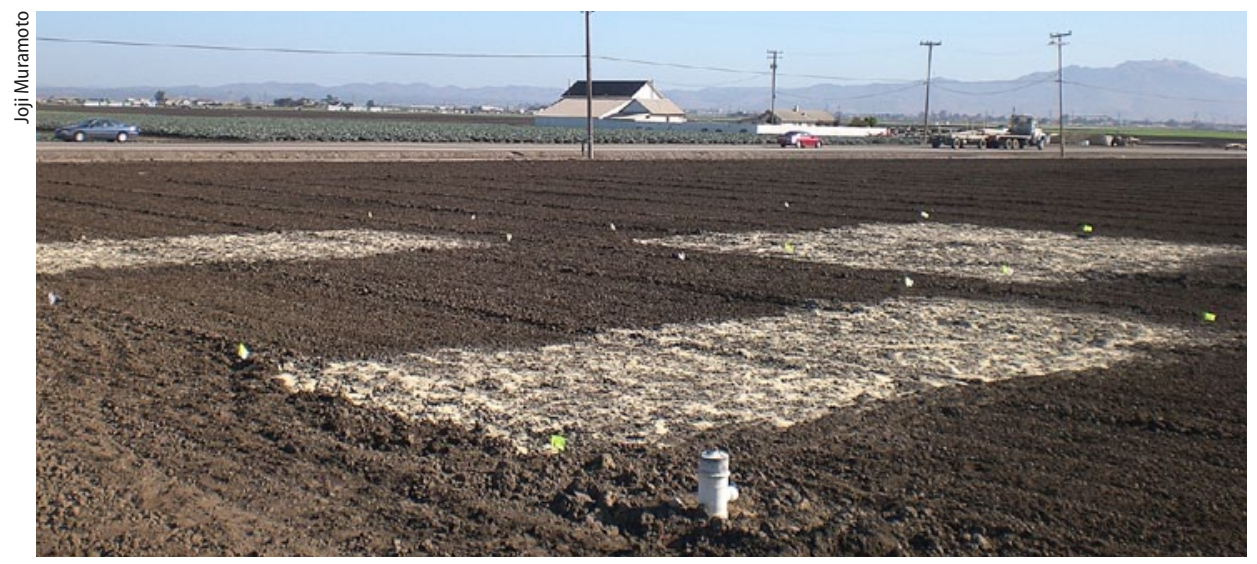

disinfestation was initiated Oct. 7 to create a saturated condition. The plots were maintained above field capacity with intermittently applied irrigation water (total of 2.5 acre-inches) from Oct. 8 to Nov. 3, 2010. Steam was applied via spike injection from a stationary steam generator for a sufficient time to raise the soil temperature to $158^{\circ} \mathrm{F}$ for 20 minutes on Oct. 13 and 14, 2010. Weed densities were measured in 25-square-foot sample areas covered with clear tarp, on Dec. 15, 2010, Jan. 21, Feb. 23 and April 6, 2011. Strawberry fruit was harvested weekly from April 28 to Sept. 15,2011 . Fruit was sorted as marketable and cull (nonmarketable) at each harvest date. Data were subjected to analysis of variance and means were separated using Fisher's protected LSD.

Trial results. Overall, the steam treatment and the steam treatment with mustard seed meal were as effective as Pic-Clor 60 in providing weed control (table 3). Anaerobic soil disinfestation plus rice bran suppressed weed densities, but it was less effective than Pic-Clor 60. No

In preparation for anaerobic soil disinfestation, rice bran is applied to the planting field. This nonchemical alternative to methyl bromide was developed in Japan and the Netherlands.
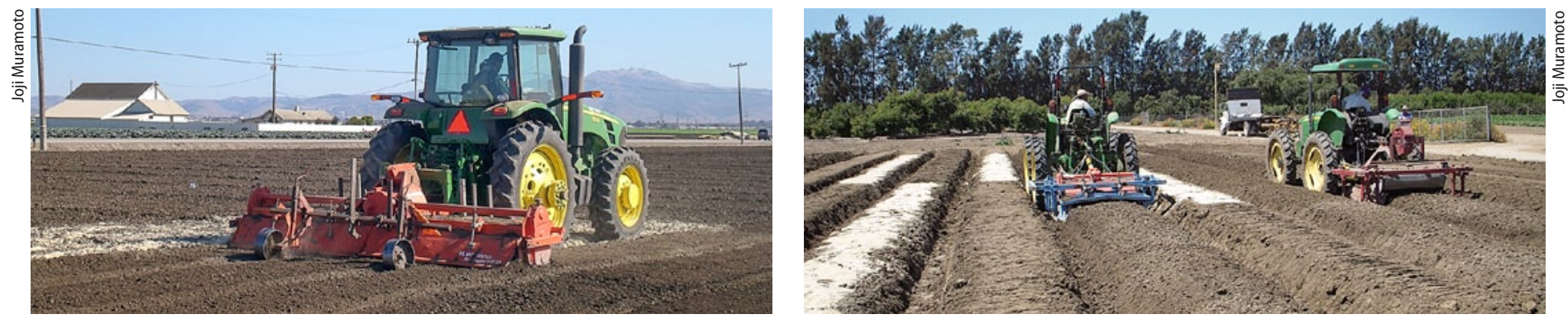

Rice bran can be incorporated before or after strawberry beds are formed. Shown are broadcasting, left, or bed top, right, application methods.

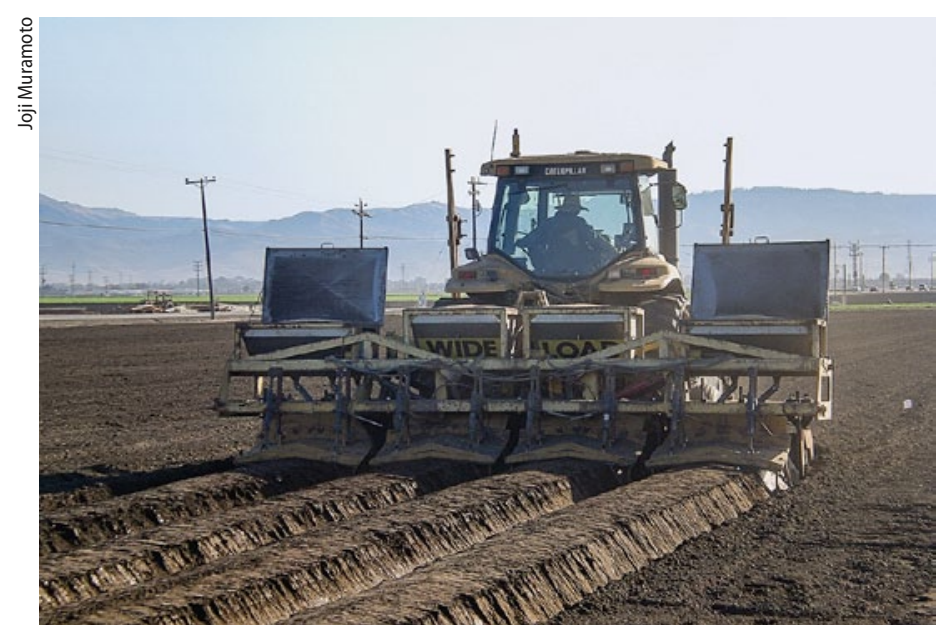

Listing of beds after incorporation of rice bran at Salinas, CA. Drip irrigation tape and then tarp will be installed so that the beds are ready to irrigate to create anaerobic conditions.

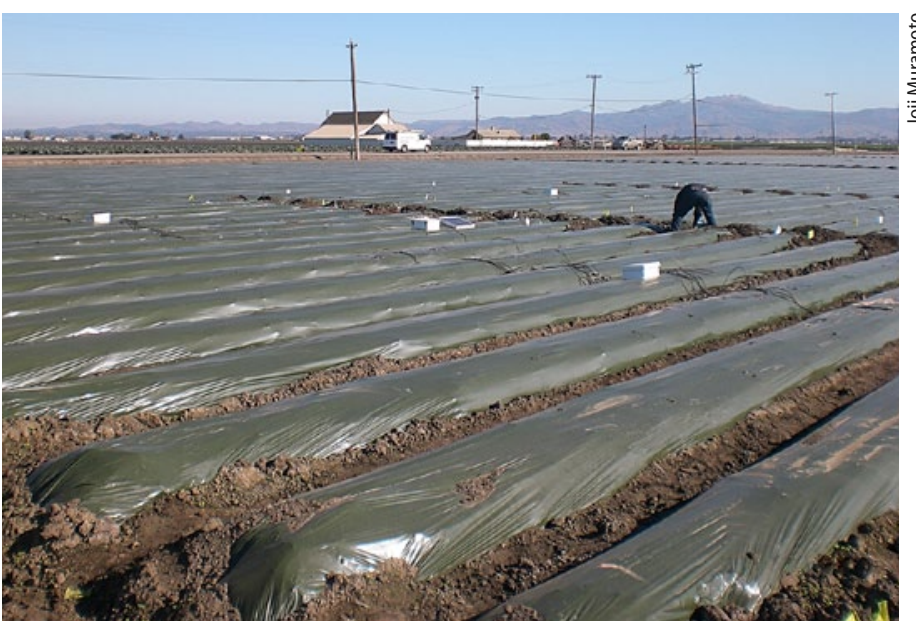

Water is applied to the covered strawberry beds to create anaerobic conditions prior to planting. Anaerobic soil disinfestation was very effective in suppressing Verticillium dahliae in soils, and it resulted in $85 \%$ to $100 \%$ of the marketable fruit yield observed with fumigated controls in coastal California strawberries. 


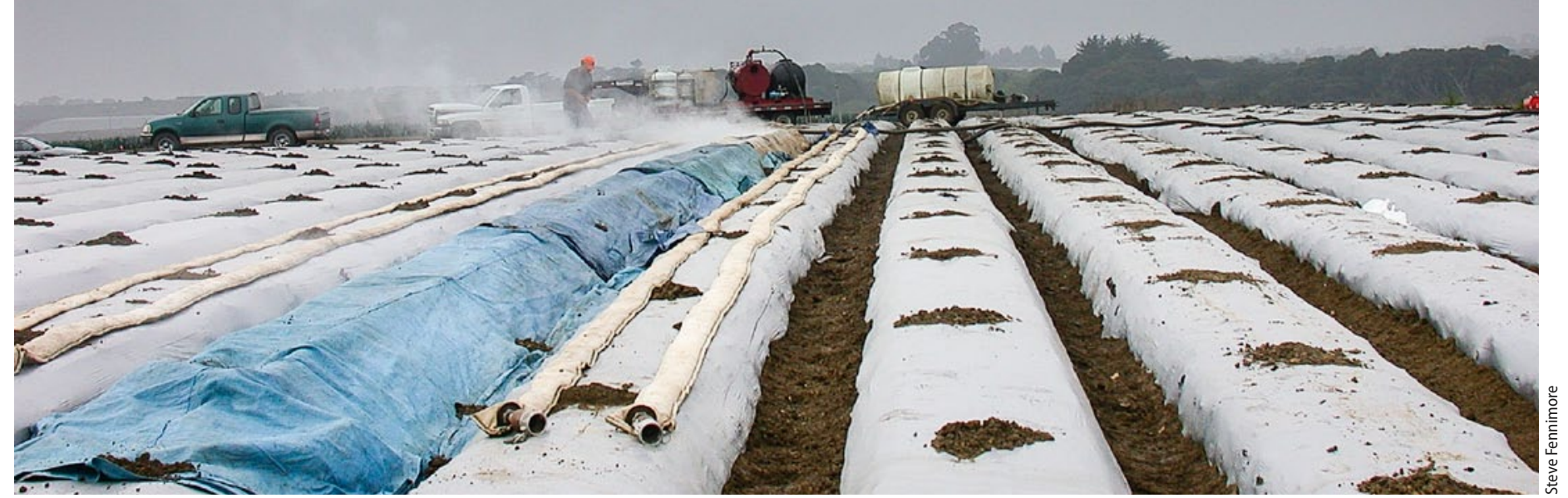

Steam is applied to strawberry beds with a stationary steamer at a commercial field near Watsonville. Raising the soil temperature to $158^{\circ} \mathrm{F}$ for 20 minutes produces soil pest control comparable to fumigants.

strawberry plant injury was observed in any of the treatments (data not shown).

Marketable yields data collected from April 28 to Sept. 15, 2011, indicate that strawberry fruit yields in the steam treatments and the anaerobic soil disinfestation treatments were comparable to those in the Pic-Clor 60 application (table 3). These data, along with data from our prior studies, show that steam is as effective as chemical fumigation; and that anaerobic soil disinfestation also produces yields equivalent to Pic-Clor 60 but may need to be combined with herbicide use in severely weed-infested sites.

The costs of the anaerobic soil disinfestation treatments with rice bran, and with rice bran plus mustard seed meal, were $\$ 1,632$ and \$3,093 per acre, respectively, including material, spreading, incorporation and irrigation (fig. 1). The cost of steam was $\$ 10,440$ per acre, compared to

TABLE 3. Treatment effect on weed density and strawberry yield April 28 to Sept. 15, 2011

\begin{tabular}{lcc}
\hline \hline Treatment & Weed density & Fruit yield \\
\hline & no. per 25 square feet & Ib/plant \\
Pic-Clor 60 & $93.5 c^{*}$ & $2.53 a$ \\
Mustard seed meal & $635.7 \mathrm{ab}$ & $1.60 \mathrm{~b}$ \\
Steam & $118.7 \mathrm{c}$ & $2.44 \mathrm{a}$ \\
Steam + mustard seed meal & $93.5 \mathrm{c}$ & $2.53 \mathrm{a}$ \\
ASD + rice bran & $495.7 \mathrm{~b}$ & $2.39 \mathrm{a}$ \\
ASD + rice bran + mustard seed meal & $568.7 \mathrm{ab}$ & $2.53 \mathrm{a}$ \\
Untreated control & $701.6 \mathrm{a}$ & $1.60 \mathrm{~b}$ \\
\hline
\end{tabular}

* Mean values within a column followed by the same letter(s) or without letters were not significantly different according to Fisher's LSD test $(P>0.05)$.

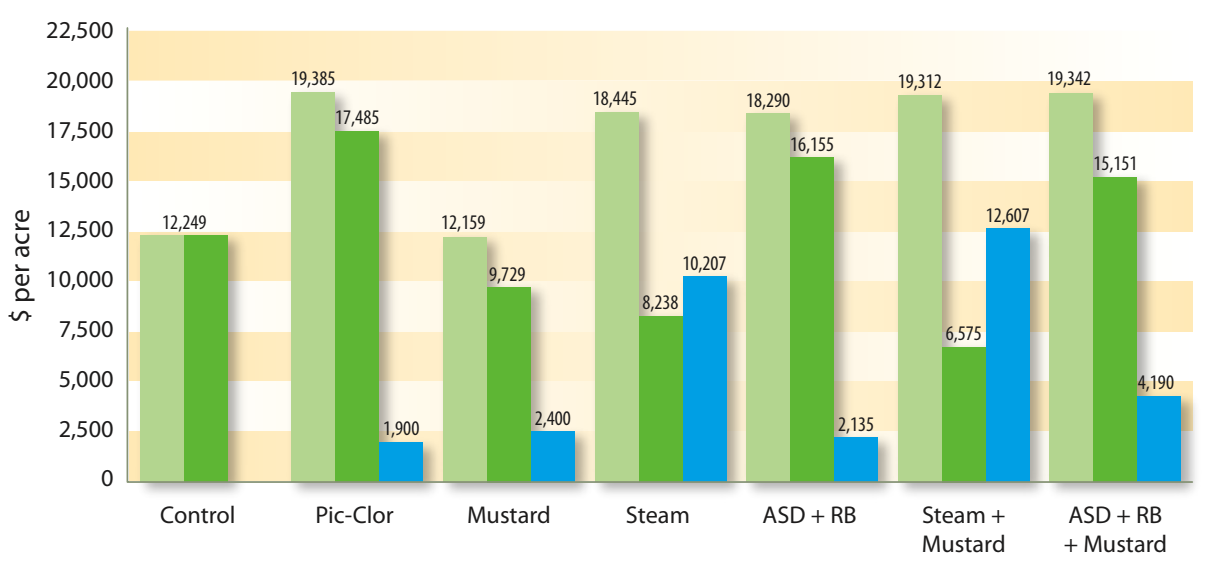

Net revenue above harvest cost $\square$ Net revenue above harvest and treatment costs $\square$ Treatment cost

Fig. 1. Cost and returns per acre for an untreated, nonfumigated control; a standard Pic-Clor 60 fumigation treatment; and various nonfumigant soil treatments at Monterey Bay Academy, 20102011. Mustard $=$ mustard seed meal. $A S D=$ anaerobic soil disinfestation. $\mathrm{RB}=$ rice bran .

\$1900 per acre for Pic-Clor 60. Therefore, although the yields and gross revenues were comparable across treatments, the net returns after treatment and harvest costs were highest for the Pic-Clor treatment, followed by the anaerobic soil disinfestation with rice bran. The lowest net revenue was for the steam plus mustard seed meal treatments due to the high cost of the steam treatment.

The cost data showed a critical need for more-efficient steam injection systems before steam can be adopted commercially. Recent advances with steam application equipment can reduce the cost of steam treatment to less than $\$ 5,500$ per acre with the potential for further cost reductions (Fennimore et al. 2012). Since 2011 we have used an automatic mobile steam applicator in our research, which lowers the labor costs relative to those reported here by approximately $50 \%$ to $70 \%$. It mixes steam with soil, allowing soil to be heated from $60^{\circ} \mathrm{F}$ to $160^{\circ} \mathrm{F}$ in 90 seconds - much more rapidly than the steam application system used here (Fennimore et al. 2012).

\section{Future options}

The phase-out of methyl bromide has proven to be a daunting task for the California strawberry industry. Not only are strawberry producers faced with the likelihood that methyl bromide will no longer be available to them by 2015, but they also must deal with increasing regulatory stringency on the use of all soil fumigants. While fumigants face an uncertain future in California, barrier films can help trap fumigants in the soil and reduce the likelihood of environmental or health impacts associated with fumigants in the atmosphere. It appears very likely in the near future that barrier films will be the only type of film approved for use with fumigants in California. 
Potential methods of strawberry production that do not use fumigants include growing plants in substrates and using steam treatments or anaerobic soil disinfestation. All of these systems are being evaluated on a much larger scale, from 1 to 10 acres, with different soil types, to determine commercial feasibility and cost effectiveness. It is not likely, nor is it desirable from a pest management perspective, that one nonfumigant system will dominate on a large percentage of the strawberry acreage. Multiple production systems, using fumigants and nonfumigants, would allow producers to rotate treatments to suppress soil pests.

\section{S.A. Fennimore is UC Cooperative Extension} Specialist and Weed Scientist, R. Serohijos is Staff Research Associate, both in Department of Plant Sciences, UC Davis, at Salinas; J.B. Samtani is Small Fruit Production Specialist, Virginia Polytechnic Institute and State University, Virginia Beach, VA; H.A. Ajwa is UCCE Specialist and Soil Scientist, Department of Plant Sciences, UC Davis, at Salinas; K.V. Subbarao is Plant Pathologist and UCCE Specialist, Department of Plant Pathology, UC Davis, at Salinas; F.N. Martin is Plant Pathologist, USDA Agricultural Research Service, Salinas; O. Daugovish is Farm Advisor, UCCE Ventura; D. Legard is Research Director, California Strawberry Commission, Watsonville; G.T. Browne is Research Plant Pathologist, USDA Agricultural Research Service, Davis; J. Muramoto is Associate Researcher, and C. Shennan is Professor, Department of Environmental Studies, UC Santa Cruz; and K. Klonsky is UCCE Specialist, Agriculture and Resource Economics, UC Davis.

We are grateful for the financial support of the USDA-ARS Pacific Area-Wide Pest Management Program for Methyl Bromide Alternatives for support of this project. We thank TriCal, Mustard Product Technologies and Raven Industries for material and technical support.

\section{References}

Anbar AD, Yung YL, Chavez FP. 1996. Methyl bromide: Ocean sources, ocean sinks, and climate sensitivity. Global Biogeochem Cy 10:175-90.

Baker KF, Roistacher CN. 1957. Chapter 9: Principles of heat treatment of soil. In: Baker KF. The U.C. System for Producing Healthy Container-Grown Plants. UC Agriculture Experiment Station Extension Service, Manual 23. p 138-61.

Blok WJ, Lamers JG, Termorshuizen AJ, Bollen GJ. 2000. Control of soilborne plant pathogens by incorporating fresh organic amendments followed by tarping. Phytopathology 90:253-9.

[CADPR] California Department of Pesticide Regulation. 2011. 2010 Annual Pesticide Use Report. Department of Pesticide Regulation, Sacramento, CA. www.cdpr. ca.gov/docs/pur/pur10rep/comrpt10.pdf (accessed May 1, 2012)

Carpenter J, Lynch L, Trout T. 2001. Township limits on 1,3-D will impact adjustment to methyl bromide phaseout. Calif Agr 55:(3)12-8

Chellemi D, Mirusso J. 2002. A new approach to fumigating soils under raised, plastic mulched beds. In: Proc Ann Int Res Conf on Methyl Bromide Alternatives and Emis sions Reductions, Nov. 6-8, 2002. Orlando, FL. Abstr. 38

Chellemi D, Mirusso J. 2006. Optimizing soil disinfestation procedures for fresh market tomato and pepper produc tion. Plant Dis 90:668-74.

[CSC] California Strawberry Commission. 2011. Acreage Survey, www.calstrawberry.com/fileData/docs/2010_ Acreage_Survey.pdf (accessed May 1, 2012).

Desaeger J, Csinos A. 2005. Phytotoxicity associated with drip-applied 1,3-dichloropropene and chloropicrin in vegetables produced with plastic mulch. HortScience 40:700-6.

Fennimore SA, Ajwa HA. 2011. Strawberry yield and weed control following fumigant application under impermeable film. Calif Agr 65:211-5.

Fennimore SA, Haar MJ, Ajwa HA. 2003. Weed control in strawberry provided by shank- and drip-applied methyl bromide alternative fumigants. HortScience 38:55-61.

Fennimore SA, Miller T, Goodhue R, Subbarao K. 2012. Evaluation of an automatic steam applicator in strawberry. In: Proc Ann Int Res Conf on Methyl Bromide Alternatives and Emissions Reductions, Nov. 6-8, 2012. Maitland, FL. Abstr. 9. www.mbao.org/.

Hochmuth G, Hochmuth R. 2003. Open-Field Soilless Culture of Vegetables. University of Florida, Cooperative Extension. http://edis.ifas.ufl.edu (accessed May 1, 2012). Ibekwe AM, Papiernik SK, Gan J, et al. 2001. Impact of fumigants on soil microbial communities. Appl Environ Microbiol 67:3245-57.
Jäderlund A, Norberg G, Zackrisson O, et al. 1998. Control of bilberry vegetation by steam treatment-effects on seeded Scots pine and associated mycorrhizal fungi. Forest Ecol Manag 108:275-85.

Katase M, Kubo C, Ushio S, et al. 2009. Nematicidal activity of volatile fatty acids generated from wheat bran in reductive soil disinfestation. Nematological Res 39:53-62. Lieten P, Longuesserre J, Baruzzi G, et al. 2004. Recent situation of strawberry substrate culture in Europe. Acta Hortic 649:193-6.

Lieten P, Longuesserre J, Pivot D. 2004. Experiences with substrates, drainage water and recirculation in strawberry culture. Acta Hortic 649:207-11

Mazzola M. 2006. Mechanisms and efficacy of Brassicaceae seed meal-induced disease control. In: Proc Ann Int Res Conf on Methyl Bromide Alternatives and Emissions Reductions, Nov. 6-9, 2006. Orlando, FL. Abstr. 63.

Medina JJ, Miranda L, Romero F, et al. 2006. Seven years' work on alternatives to methyl bromide (MB) for strawberry production in Huelva (Spain). Acta Hortic 708:205-10.

Minuto G, Minuto A, Gullino ML, Garibaldi A. 2003. II calore umido per la disinfestazione del terreno: Osservazioni sulle condizioni di applicazione. Informatore Fitopatologico 10:66-72.

Momma N. 2008. Biological soil disinfestation (BSD) of soilborne pathogens and its possible mechanisms. JarqJpn Agr Res Q 42:7-12.

Moyls AL, Hocking RP, Neilsen GH, Hogue EJ. 1994. Apple tree growth response in greenhouse pot tests using heat-treated replant soil versus orchard replanted trees with in situ heated soil. Acta Hortic 363:57-63.

[NASS] National Agricultural Statistics Service. 2011 Vegetables 2010 Summary. Agricultural Statistics Board NASS USDA, Washington, DC. 78 p.

Papiernik SK, Yates SR, Gan J. 2001. Assessing the permeability of agricultural films. 222nd American Chemical Society Meetings. Aug. 26-30, 2001. Chicago, IL. Paper No. AGR099

Qian Y, Kamel A, Stafford C, et al. 2011. Evaluation of the permeability of agricultural films to various fumigants. Environ Sci Technol 45:9711-8.

Rosskopf EN, Kokalis-Burelle N, Butler D, et al. 2010 Development of anaerobic soil disinfestation for Florida vegetable and flower production. In: Proc Annual Int Res Conf on Methyl Bromide Alternatives and Emissions Reductions, Nov. 2-5, 2010. Orlando, FL. Abstr. 84

Samtani JB, Ajwa HA, Weber JB, et al. 2011. Evaluation of non-fumigant alternatives to methyl bromide for weed control and crop yield in California strawberries (Fragaria ananassa L.). Crop Prot 30:45-51.
Samtani JB, Gilbert C, Weber JB, et al. 2012. Effect of steam and solarization treatments on pest control, strawberry yield and economic returns relative to methyl bromide. HortScience 47:64-70.

Santos BM, Gilreath JP, Motis TN. 2005. Managing nutsedge and stunt nematode in pepper with reduced methyl bromide plus chloropicrin rates under virtually impermeable films. HortTechnology 15:596-9.

Shennan C, Muramoto J, Baird G, et al. 2011. Anaerobic soil disinfestation: California. In: Proc Ann Int Res Conf on Methyl Bromide Alternatives and Emissions Reductions, Oct. 31-Nov. 2, 2011. San Diego, CA. Abstr. 44.

Strand LL 2008. Integrated Pest Management for Strawberries ( $2^{\text {nd }}$ ed.). UC Statewide Integrated Pest Management Project, UC ANR Pub 3351. Oakland, CA

Tanaka S, Kobayashi T, Iwasaki K, et al. 2003. Properties and metabolic diversity of microbial communities in soils treated with steam sterilization compared with methyl bromide and chloropicrin fumigations. Soil Sci Plant Nutr 49:603-10.

[USDS] United States Department of State. 2008. Methyl Bromide Critical Use Nomination for Preplant Soil Use for Strawberries Grown for Fruit in Open Fields. www.epa. gov/ozone/mbr/CUN2008/CUN2008_StrawberryFruit.pdf (accessed May 1, 2012).

[VCAC] Ventura County Agricultural Commissioner. 2011. Fumigant Use Regulations. http://ceventura.ucdavis.edu/ Com_Ag/comveg/Strawberry/Recent_Meetings/Fumigants_4_11/(accessed May 1, 2012)

Wang D, Yates SR. 1998. Methyl bromide emission from fields partially covered with a high-density polyethylene and virtually impermeable film. Environ Sci Tech 32:2515-8.

Wang D, Yates SR, Ernst FF, et al. 1997. Reducing methyl bromide emission with a high barrier plastic film and reduced dosage. Environ Sci Tech 31:3686-91.

Wang D, Yates SR, Gan J, Knuteson JA. 1999. Atmospheric volatilization of methyl bromide, 1,3-dichloropropene, and propargyl bromide through two plastic films: Trans fer coefficient and temperature effect. Atmos Environ 33:401-7.

Wilhelm S, Paulus AO. 1980. How soil fumigation benefits the California strawberry industry. Plant Dis 64:264-70.

Yamamoto T, Ultra VU Jr, Tanaka S, et al. 2008. Effects of methyl bromide fumigation, chloropicrin fumigation, and steam sterilization on soil nitrogen dynamics and microbial properties in a pot culture experiment. Soil Sci Plant Nutr 54:886-94

Zackrisson O, Norberg G, Dolling A, et al. 1997. Site preparation by steam treatment: Effects on forest vegetation control and establishment, nutrition, and growth of seeded Scots pine. Can J Forest Res 27:315-22. 